\title{
TEORI HUKUM CHAOS BERKAITAN DENGAN TINDAK PIDANA PERBANKAN
}

\author{
Suparmin \\ Fakulltas Hukum Universitas Wahid Hasyim Semarang \\ suparmin@unwahas.ac.id
}

\begin{abstract}
Abstrak
Masalah Bantuan Likuiditas Bank Indonesia-selanjutnya disebut BLBI hingga kini belum juga terselesaikan. Opsi kebijakan yang diambil Pemerintah untuk mengatasi krisis perekonomian ditahun 1997, kini masih menimbulkan polemik berkepanjangan dan semakin bergerak kedataran yang semakin komplek dan bersifat multi dimensi. Perubahan distribusi kekayaan dan kekuasaan politik akan memperkuat posisi kelompok kaya, kalangan bisnis besar dan para penghisap dan pemupuk rente ekonomi atas pengorbanan masyarakat bawah. Ideologi yang berbahaya ini kita ungkapkan dengan mengutip pernyataan seorang ahli ekonomi yang mampu menghormati hak-hak rakyat dan pro-rakyat berkebangsaan Amerika Serikat, yaitu Kenneth Galbraith (1992): The privatization of social services and public enterprises are aimed at altering property relations and hence distribution of wealth and political power toward the greater empowerment of the rich, big business and the rentiers at the cost of "the underclass". Situasi ini telah terlihat di Indonesia dan situasi ini akan diperkukuh oleh IMF dengan memasukkan kekuatan asing. Kami merasa prihatin dan ikut malu jikalau elit kekuasaan dan para intelektual di Indonesia tidak mampu melihat atau merasakan kecenderungan ini sebagai divergensi terhadap pesan konstitusi.
\end{abstract}

Kata kunci: bantuan likuiditas, Bank Indonesia, teori chaos.

\section{A. Pendahuluan}

Konferensi Meja Bundar (KMB) yang berlangsung di Den Hag, Belanda tahun 1949 merupakan tonggak sejarah lahirnya Bank sentral Indonesia. Salah satu keputusan penting KMB adalah menunjuk De Javasche Bank NV sebagai bank sentral. De Javasche Bank adalah Bank komersial dan sirkulasi milik pemerintah kolonial Hindia Belanda yang sudah berdiri sejak tahun 1828.

Namun fakta sejarah juga mencatat bahwa sejak tahun 1946, bangsa Indonesia telah memiliki sebuah Bank cukup besar yaitu Bank Negara Indonesia 
(BNI) 1946, yang awalnya berstatus sebagai bank sentral dan kemudian oleh keputusan KMB diubah menjadi Bank Pembangunan, kemudian dengan melakukan nasionalisasi De Javasche Bank, dengan melalui realisasi dengan Keputusan Pemerintah Nomor 118 tertanggal 2 Juli 1951, seorang putra Bangsa Indonesia menjadi presiden baru bank tersebut, mengakhiri tradisi sebelumnya yang selalu dijabat oleh orang Belanda, melalui Keputusan Presiden No. 123 tanggal 12 Juli 1951, Syafrudin Prawira Negara diangkat sebagai presiden baru bank sentral yang sekaligus mencerminkan keinginan kuat pemerintah untuk membangun bank sentral yang mandiri dan bebas dari pengaruh kolonial.

Langkah tersebut dipertegas dengan Undang-Undang No 11 tahun 1953 tentang pokok-pokok Bank Sentral yang dapat disebut merupakan jawaban atas kehendak bangsa yang berdaulat dibidang moneter dan ekonomi di negeri sendiri (a symbol of sovereignity in monetary and economic affairs). Undang-Undang menggariskan peranan pokok yang harus dijalankan oleh Bank Indonesia, yakni sebagai penjaga stabilitas moneter, mengedarkan uang, mengembangkan sistem perbankan, mengawasi kegiatan perbankan dan penyaluran kredit bank. Saat itu bank masih merangkap sebagai bank komersial seperti yang dijalankan oleh De Javasche Bank. Melalui Undang-Undang No. 13 tahun 1968 peran komersial Bank Indonesia dicabut. Misi yang diemban BI, tercermin dalam pasal 7 UU Bank Sentral Asia tentang tugas pokok BI, yaitu (1) mengatur, menjaga dan memelihara stabilitas nilai rupiah. (2) Mendorong kelancaran produksi pembangunan serta memperluas kesempatan kerja guna meningkatkan taraf hidup rakyat. Rumusan tugas itu rupanya muncul antara lain lantaran keterlibatan BI yang intensif membantu program pemerintah, terutama sejak tahun 1960.

Penegasan bahwa BI juga bertugas sebagai "kasir negara" tercantum pada Pasal 34, Pasal 36, dan Pasal 38 UU No. 13/1968 tentang Bank Sentral, ini merupakan fungsi ketiga BI sebagai Bank Sentral, sekaligus menegaskan fungsi BI yang lebih jelas dibanding Undang-Undang No. 11 tahun 1953. Sedangkan 
fungsi keempat sebagai bankers bank mengharuskan BI bertindak sebagai lender of last resort dalam keadaan genting atau mendesak.

Kecuali BI berlaku sebagai fungsi Bank sirkulasi, pasal 26 ayat (1) dan ayat (2) UU No 11/1953 yang menegaskan BI mempunyai hak tunggal mengeluarkan uang kertas dan uang logam. Uang yang dikeluarkan BI merupakan satu-satunya uang alat pembayaran yang sah di Republik Indonesia.

Pengawasan dan pembinaan Bank serta urusan kredit bank juga menjadi tanggung jawab BI, fungsi ini diatur dalam Pasal 29 ayat (1) UU No.13/1968, yang memberikan wewenang kepada BI untuk meminta laporan keuangan Bank serta melakukan pemeriksaan segenap kegiatan Bank. Kewenangan ini sangat penting bagi BI, karena sekaligus menjadi sarana untuk mengawasi pelaksanaan segala ketentuan dibidang perbankan dan usaha kredit. ${ }^{60}$

Masalah Bantuan Likuiditas Bank Indonesia-selanjutnya disebut BLBI hingga kini belum juga terselesaikan. Opsi kebijakan yang diambil Pemerintah untuk mengatasi krisis perekonomian ditahun 1997, kini masih menimbulkan polemik berkepanjangan dan semakin bergerak kedataran yang semakin komplek dan bersifat multi dimensi.

\section{B. Metode Penelitian}

Penelitian ini tergolong dalam ranah socio-legal research, yang melihat hukum sebagai tatanan normatif yang dioperasionalisasikan dalam kehidupan atanan sosial tertentu. Pendekatan yang digunakan adalah hermeneutic dalam setudi hukum sangat penting karena digambarkan sebagai perkembaan studi teori tentang interprestasi dan sistem pemahaman tentang teks perundang-undangan. Hermeneutic berasal dari kata 'Hermes' yaitu Dewa Yunani yang menjalankan tugas sebagai utusan Illahi untuk menyampaikan dan mengiterpretasikan kabar kepada umat manusia sebagai penerima, baik berita baik maupun buruk.

${ }^{60}$ Mulyo Mardi, Bank Indonesia Menuju Independensi Bank Sentral, PT. Mardi Mulyo, Jakarta, Mei $2000: 1-5$. 


\section{Hasil Penelitian dan Pembahasan}

Pada 31 Oktober 1997, Letter Of Intent (LOI) Indonesia-IMF ditandatangani Menteri Keuangan dan Gubernur Bank Indonesia, yang antara lain butir 4 menyebutkan "seluruh biaya yang berkaitan dengan penutupan bank dan rehabilitasi bank pemerintah menjadi beban pemerintah melalui APBN. Caranya dengan menerbitkan surat utang (bond) yang dijamin pemerintah".

Berdasarkan Undang-Undang No. 13/1968, Bank Indonesia berwenang memberikan kredit likuiditas kepada bank yang kondisinya darurat. Pemberian kredit likuiditas dalam keadaan darurat selalu mengandung arti tidak memberlakukan skors kliring bagi bank bersaldo debet. Dengan demikian, kebijakan tak memberlakukan skorsing kliring kepada bank dalam kondisi darurat pada saat terjadinya krisis moneter di atas, sesuai dengan Undang-Undang No. 13 tahun 1968; Sebuah kebijakan, termasuk pemberian BLBI, dapat disalahkan dari aspek hukum bila memenuhi unsur:

1. pelampauan kewenangan dalam menetapkan kebijakan; dan atau

2. penyalahgunaan wewenang dalam menetapkan kebijakan.

Semestinya, setiap memberikan BLBI/Sianturi, harus ada suatu perjanjian baik secara nota riil maupun dibawah tangan, antara BI dengan bank penerimanya, perjanjian itu diikuti pengikatan dan atau penyerahan jaminan, disertai surat pernyataan pemilik dan pengurus bagi bank yang mengikuti program penjaminan. Bentuk perjanjian pengikatan hutang dibawah tangan yang dikenal di Bank Indonesia, antara lain, berupa perjanjian karena persekot dalam rekening koran dengan promes-promes sebagai jaminan. Dalam istilah teknis disebut akta $\mathrm{F}$ pengikatan hutang dibawah tangan lainnya misalnya: persetujuan direksi atau pihak yang berwenang dari bank atas persyaratan pada surat penegasan kredit $(\mathrm{SPK}){ }^{61}$

Setiap kebijakan punya opsi, setiap kebijakan punya cost and benefit. Dari cost and benefit tersebut, masyarakat bisa melihat dan mengerti pemerintah

\footnotetext{
${ }^{61}$ Bank Indonesia, Mengurai Benang Kusut BLBI Bank Indonesia, Perpustakaan Nasional: Katalog Dalam Terbitan (KDT) Bank Indonesia, Jakarta, Februari 2002:8-15/ fide44-66.
} 
berpihak pada siapa. Kepekaan pemerintah/legislatif saat ini, sudah tidak ada lagi, menganggap remeh penderitaan rakyat.

Pemerintah secara sepihak menaikkan tarif, sementara di bidang lain, masyarakat melihat, pemerintah tidak sungguh-sungguh memulihkan ekonomi, karena pemerintah tidak sungguh-sungguh memberantas kolusi, korupsi dan nepotisme $(\mathrm{KKN})$. Terjadi kontradiksi di dalam pengambilan kebijakan. Kebijakan itu sendiri tidak menguntungkan masyarakat, sehingga otomatis ditolak mentah-mentah.

Sesuai pasal 1338 KUH Perdata, kesepakatan itu berlaku mengikat bagi para pihak, yaitu pemerintah dan BI, dalam bahasa hukum sesuai dengan "asas pacta sun servenda", maknanya para pihak tak dapat menarik diri dari ketentuan dalam kesepakatan bersama, atau mengubahnya secara sepihak, tanpa persetujuan pihak lainnya. Mereka juga harus melaksanakan isi kesepakatan dengan suatu itikat yang baik.(fide hal 98).

Dalam kajian sosiologis hukum dipandang sebagai fenomena empirik yang sifatnya hanya dapat dimengerti jika hukum itu dipandang dalam hubungannya dengan masyarakat. Max Weber berpendapat bahwa hukum adalah suatu "Order" itu cara eksternal dijamin melalui kemungkinan penggunaan paksaan dan kekerasan, baik secara fisik maupun kejiwaan, untuk menghasilkan persesuaian atau membahas kekerasan, yang akan diterapkan oleh orang-orang yang secara khusus sudah disiapkan untuk tujuan itu. Tentu saja yang dimaksud Max Weber dengan orang-orang khusus tadi adalah kaum profesi hukum, mencakup Hakim, Jaksa, Pengacara, Notaris dan Polisi, dan Kehakiman. Oleh karena ancaman paksaan merupakan unsur yang mutlak agar suatu kaedah dapat dikategorikan sebagai hukum, maka tentu saja unsur paksaan itupun erat kaitannya dengan efektif atau tepatnya suatu ketentuan atau aturan hukum. Jika suatu aturan hukum tidak efektif, salah satu pertanyaan yang dapat muncul adalah apa yang terjadi dengan ancaman paksaannya? Mungkin tidak efektifnya hukum karena ancaman paksanya kurang berat, mungkin juga karena ancaman paksanya tidak terkomunikasi secara memadai pada warga masyarakat. 
Keadaan yang demikian itu berbeda sekali dengan pandangan atau konsep hukum yang lain, seperti yang diajarkan oleh Aliran Sejarah. Pemuka utama dari Ajaran tersebut, yaitu Friedrich Karl von Savigny, yang juga disebut sebagai pendiri Aliran Sejarah tersebut, mengatakan, bahwa hukum itu merupakan ekspresi dari kesadaran umum atau semangat dari rakyat (Volksgeist). Savigny mempertahankan pendapat, bahwa hukum itu pertama-tama dilahirkan dari kebiasaan dan kesadaran umum masyarakat, kemudian dari keputusan hakim, tetapi bagaimana pun juga diciptakan oleh kekuatan-kekuatan dari dalam yang bekerja secara diam-diam, dan tidak oleh kemauan sendiri dari pembuat undangundang. ${ }^{62}$

Untuk mengkaji lebih dalam lagi tentang realitas sosial tersebut di atas, maka kajiannya harus dilakukan berdasarkan teori-teori hukum yang relevan agar dirasakan manfaatnya bagi masyarakat. Ilmu hukum sekarang ini Satjipto Rahardjo menyatakan, teori hukum secara garis besar dibagi dalam dua golongan teori :

a. Teori normatif dan teori empirik

Teori normatif berusaha untuk mempertahankan hukum positif, artinya teori normatif berusaha memberi tuntunan bagaimana hukum positif dijalankan, sedangkan teori empirik tidak ditarik dari hukum positif tetapi ditarik dari dua empirik yang terjadi di masyarakat. Berdasarkan realitas masyarakat, lalu dibangun teori.

b. Teori berbasis keteraturan (order) dan ketidakteraturan (disorder)

Teori keteraturan ini muncul oleh karena orang yang membangun teori itu beranggapan bahwa hukum itu sesuatu yang serba teratur (orderly), yang masuk dalam klasifikasi ini adalah : teori positif dan teori struktural fungsional. Sedangkan teori berbasis ketidakteraturan beranggapan bahwa tidak selalu

${ }^{62}$ Prof. Dr. Satjipto Rahardjo, SH, Ilmu Hukum, Penerbit PT. Citra Aditya Bakti, Bandung, 1996, hal 206 
hukum berdasarkan keteraturan tetapi juga ketidakteraturan (disorder). Teori ketidakteraturan ini meliputi Chaos theory atau teori compleksitas.

Menyangkut ketidakteraturan (disorder), Charles Stamford dalam bukunya The Disorder of Law, A Critique of Legal Theory (1989 : 160) mengemukakan teori sekaligus kritik terhadap teori-teori hukum yang dibangun berdasarkan konsep sistem (sistemik) atau keteraturan menurutnya, tidak selalu teori hukum itu didasarkan pada teori sistem (mengenai) hukum, karena pada dasarnya hubungan-hubungan yang terjadi dalam masyarakat menunjukkan adanya hubungan yang tidak simetris. Inilah ciri khas dari sekalian hubungan sosial yang dipersepsikan secara berbeda oleh para pihak. Dengan demikian apa yang dipermukaan tampak sebagai teratur tertib, jelas dan pasti sebenarnya penuh dengan ketidakpastian.

Chaos Theory mulai berkembang dalam ilmu fisika. Dalam fisika, yang sering dipandang sebagai fondasi sains, bangunan materialisme dikukuhkan oleh tonggak-tonggak fisika mekanika Newton yang memandang alam semesta sebagai sebuah mesin mekanik rekayasa yang tersusun atas komponen-komponen material yang bergerak dan saling terhubungkan secara deterministik. Ciri yang menonjol dari pandangan alam semesta yang mekanistik ini adalah reduksionistik (Mizan dan PPS Studi Pembangunan ITB : $2000: 6-7)$.

Dalam kacamata fisika Newton, alam semesta tampak teratur atau terprediksi, ada gaya dan kaidah yang mengatur beroperasinya gaya tersebut. Inilah landasan ide bahwa alam semesta beroperasi seperti jam mekanik, akan tetapi dibantah oleh Edward Lorenz pada tahun 1960 (Seri Penerbitan Sains, hal 10 - 11). Bahkan Ian Stewart mengatakan, bahwa Chaos adalah tingkah laku yang sangat kompleks, ireguler dan random di dalam sebuah sistem yang deterministik. Chaos adalah satu keadaan dimana sebuah sistem tidak bisa 
diprediksi dimana ia akan ditemukan ditempat berikutnya, sistem ini bergerak secara acak. $^{63}$

Apa yang dikemukakan di atas menunjukkan bahwa teori Newton tak dapat menjelaskan realitas yang serba kompleks dan relatif hingga menyebabkan teorinya itu gugur. Sama halnya dengan teori Newton, menurut Satjipto Rahardjo, teori positivisme hukum juga membuang kenyataan yang mengganggu keutuhan dan menganggapnya sebagai kenyataan yang salah dan menyimpang. Teori positivis dogmatis hanya mau melihat tubuh hukum sebagai suatu tatanan yang logis rasional, tertib teratur, tak dapat menerima ketidakteraturan. Penerimaannya akan merusak teori keteraturan yang berarti teori itu menjadi roboh.

Keteraturan dan ketidak teraturan adalah dua hal atau sifat yang berseberangan (Satjipto Rahardjo, Mengajarkan Keteraturan, 2000 : 19). Pada tulisan lain (Ilmu Hukum, Pencarian, 2000 : 38) Satjipto Rahardjo juga mengatakan :

Ilmu hukum mulai tertarik pada teori kekacauan tersebut, oleh karena ia juga mengalami keadaan yang hampir serupa. Kaum positivis juga yakin bisa menjelaskan hukum dan prosesnya secara pasti juga tidak dapat mengakomodasi kenyataan-kenyataan yang muncul tidak beraturan dan kacau. Memindahkan dan menggunakan teori kekacauan mempunyai arti yang signifikan sekali, oleh karena akan menolong ilmu hukum untuk menjadi sebenar ilmu.

Berdasarkan uraian di atas, dapat ditarik manfaat teori hukum sebagai berikut :

1. Dengan deskripsi uraian di atas dapat dijelaskan bahwa di luar tatanan (order) hukum yang berkualitas negara, secara empirik terdapat tatanan sosial (sosial order) dan transendental yang lebih luas yang membantu agar tugas dan fungsi Polri dapat mencapai hasil yang lebih optimal.

${ }^{63}$ Yasraf Amir Pilang, Sebuah Dunia Yang Menakutkan, Mesin-mesin Kekerasan Dalam Jagat Raya Chaos, Mizan, Bandung, 2001, hal : 305. 
2. Keberadaan polisi informal atau polisi alternatif yang secara empirik lebih dulu ada mendahului keberadaan polisi formal atau terstruktur menunjukkan bahwa teori hukum selalu tertatih-tatih dan berada di belakang fakta sosial. Oleh karena itu teori hukum (empirik) akan memberi manfaat dalam menyelesaikan masalah konkrit maupun pembangunan hukum pada umumnya.

3. berkenaan dengan hal-hal di atas, maka pemahaman kita tentang ilmu hukum menjadi lebih luas karena tidak terbatas pada pemahaman teori hukum normatif atau hukum positiv seperti yang ada selama ini karena hukum itu bukan semata-mata rule and logic akan tetapi social structure and behavior. Atau menurut O.W. Halmes : the life of law has not been logic but experience.

4. Bahwa hukum berkembang sesuai dengan dinamika masyarakat (polisi yang bersifat antagonis menjadi protagonis menuju pada polisi masyarakat). Oleh karena itu perkembangan hukum akan dapat melahirkan teori hukum baru dan memperkaya hukum itu sendiri.

5. Implementasi peran serta masyarakat sering dilakukan dalam bentuk pelanggaran hukum seperti perbuatan main hakim sendiri. Hal ini menunjukkan bahwa hukum (peraturan perundang-undangan) sebagai sistem yang dikatakan teratur, ternyata penuh dengan ketidakteraturan. Oleh karena itu memindahkan dan menggunakan teori kekacauan (Chaos Theory) mempunyai arti yang signifikan sekali, karena akan menolong ilmu hukum untuk menjadi sebenar ilmu.

6. Semakin tinggi teori hukum itu, semakin berkualitas pula ilmu hukum itu sendiri. Logika seperti itu akan dapat dijadikan dasar untuk mendekonstruksi ilmu hukum yang ada sekarang, karena apa yang mapan sekarang ini tidak persis sama dengan yang benar.

Perubahan distribusi kekayaan dan kekuasaan politik akan memperkuat posisi kelompok kaya, kalangan bisnis besar dan para penghisap dan pemupuk rente ekonomi atas pengorbanan masyarakat bawah. Ideologi yang berbahaya ini kita ungkapkan dengan mengutip pernyataan seorang ahli ekonomi yang mampu menghormati hak-hak rakyat dan pro-rakyat berkebangsaan Amerika 
Serikat, yaitu Kenneth Galbraith (1992): The privatization of social services and public enterprises are aimed at altering property relations and hence distribution of wealth and political power toward the greater empowerment of the rich, big business and the rentiers at the cost of "the underclass". Situasi ini telah terlihat di Indonesia dan situasi ini akan diperkukuh oleh IMF dengan memasukkan kekuatan asing. Kami merasa prihatin dan ikut malu jikalau elit kekuasaan dan para intelektual di Indonesia tidak mampu melihat atau merasakan kecenderungan ini sebagai divergensi terhadap pesan konstitusi.

Disamping itu telah terjadi apa yang disebut Domhoff (1970) sebagai situasi self-reinforcing antara jaringan kekuasaan ekonomi dengan jaringan kekuasaan politik. Masuknya unsur-unsur asing berkolaborasi dengan para kompradornya di Indonesia yang jelas merupakan pihak yang lemah, akan menjerumuskan Indonesia kembali menjadi negeri koloni asing. Terbentuklah aliansi yang terdiri dari elit kekuasaan, kelompok bisnis besar, kelompok penghisap dan pemupuk rente ekonomi, dan kelompok investor asing yang menguasai sebagian besar nilai tambah ekonomi nasional atau Produk Domestik Bruto. Sebagian besar rakyat yang menjadi anggota masyarakat pinggiran, dalam konstelasi sosial-ekonomi yang deprived dan tersubordinasi, yang kedudukannya sama dengan di zaman cultuurstelsel Hindia-Belanda bersama "Bupati-bupati Lebak" sebagai pendukung-pendukungnya. Disamping itu, banyak yang tidak menyadari bahwa Adam Smith pun sebagai peletak dasar pemikiran ekonomi klasik menolak mekanisme pasar bebas jikalau mekanisme pasar bebas ini menghancurkan kepentingan sosial (Sutherland, 1993 dan Sinha, 1995) ${ }^{64}$.

Paling tidak - sampai saat ini rasa-rasanya masih belum ada analisis secara komprehensif yang disusun untuk mengevaluasi reformasi perbankan yang sudah berjalan selama lima tahun (1998-2002). Di dalam situs BPPN

${ }^{64}$ Prof. Dr. Sritua Arif, IMF/Bank Dunia dan Indonesia, Muhammadiyah University Press, Surakarta, 2001:115-116. 
(Badan Penyehatan Perbankan Nasional), memang dapat ditemukan berbagai program reformasi perbankan, termasuk prestasi yang telah dicapainya. Namun demikian untuk sektor perbankan, analisis BPPN tampaknya terfokus pada ruang lingkup bank swasta yang diambil-alih dan direkapitulasi, sedangkan kondisi bank di luar pengawasan BPPN tidak tercakup dalam analisis tersebut.

Sekedar untuk mengingatkan kembali apa yang terjadi pada saat krisis perbankan nasional terjadi pada tahun 1997. Krisis perekonomian nasional yang berlanjut kepada krisis perbankan nasional ditandai dengan merosotnya nilai mata uang rupiah yang sangat parah. Kondisi tersebut mengundang konsekuensi melonjaknya suku bunga dan dihentikannya perpanjangan (rollover) fasilitas kredit oleh kreditor luar negeri. Dampak dari itu sebagian konglomerat dan bank mengalami kesulitan keuangan.

Disaat kondisi yang belum begitu kondusif, dilain pihak pemerintah justru memenuhi rekomendasi IMF pada bulan November 1997 untuk menutup 16 bank tanpa adanya kriteria penutupan yang jelas dan tidak tersedianya informasi mengenai kesehatan bank-bank yang belum ditutup (Fane dan Mc. Leod, 2001). Jumlah simpanan yang dijamin oleh pemerintah pada saat itu dibatasi hanya sampai dengan Rp 20 juta per rekening, sehingga kondisi tersebut menyebabkan semakin merosotnya tingkat kepercayaan penabung terhadap perbankan Indonesia.

Menghadapi kondisi demikian, BI (Bank Indonesia) sebagai lender of the last resort akhirnya mengucurkan BLBI (Bantuan Likuiditas Bank Indonesia) untuk menutupi bank-bank yang mengalami rush (penarikan besarbesaran). Untuk mencegah adanya rush yang berkepanjangan, pada akhir 
bulan Januari 1998, pemerintah menerbitkan blanket guarantee system untuk memulihkan tingkat kepercayaan masyarakat kepada perbankan nasional ${ }^{65}$.

1. Undang-Undang No 24 Tahun 1999.

Setiap penduduk wajib memberikan keterangan dan data mengenai kegiatan Lalu Lintas Devisa yang dilakukannya, secara langsung atau melalui pihak lain yang ditetapkan oleh Bank Indonesia; barang siapa dengan sengaja tidak memenuhi kewajiban sebagaimana dimaksud dalam Pasal 3 ayat (2) diancam dengan pidana denda sekurang-kurangnya Rp 250.000.000,-(dua ratus lima puluh juta rupiah) dan paling banyak Rp 1.000.000.000,- (satu milyar rupiah).

2. Undang-Undang Republik Indonesia Nomor 7 Tahun 1992 Tentang Perbankan. Sebagaimana telah diubah Dengan Undang-Undang Nomor 10 Tahun 1998, tentang rahasia Bank antara lain Pasal 40 ayat (1). Bank wajib merahasiakan keterangan mengenai Nasabah Penyimpan dan Simpanannya, kecuali hal sebagaimana dimaksud dalam pasal 41, pasal 41A, pasal 42, pasal 43, pasal 44, dan pasal 44A.

Dalam rangka meningkatkan fungsi kontrol sosial terhadap lembaga perbankan, ketentuan mengenai Rahasia Bank yang selama ini sangat tertutup harus ditinjau ulang, karena cenderung melindungi perlakuan menyimpang oleh pelaku kejahatan perbankan. Rahasia Bank dimaksud merupakan salah satu unsur yang harus dimiliki oleh setiap bank sebagai lembaga kepercayaan masyarakat yang mengelola dana masyarakat, tetapi tidak seluruh aspek yang ditatausahakan bank merupakan hal-hal yang dirahasiakan. Pemeriksaan terhadap bank yang dilakukan oleh Akuntan Publik adalah pemeriksaan setempat yang merupakan bentuk pendelegasian wewenang Bank Indonesia selaku otoritas pembina dan pengawas bank. Dengan pokok-pokok ketentuan yang ditetapkan oleh Bank Indonesia memuat antara lain:

65 DR. Krisna Wijaya MBA, 5 Tahun Reformasi Indonesia : "Lima Tahun Reformasi Perbankan (1998-2002)"; Beberapa Cacatan, Pengurus Daerah Persatuan Purnawirawan POLRI Daerah Jawa Tengah, Semarang, 2003:95. 
a. jenis, prosedur, dan ruang lingkup pemeriksaan;

b. jangka waktu dan pelaporan hasil pemeriksaan;

c. tindak lanjut hasil pemeriksaan.

Badan khusus mempunyai wewenang untuk melakukan penagihan paksa, tatacara pelaksanaannya tetap memperhatikan aspek kepastian hukum dan keadilan. Untuk memperoleh keterangan dimaksud, badan khusus dapat meminta bantuan alat negara penegak hukum yang berwenang. Pihak terafiliasi dan pihakpihak lain yang terlibat atau patut diduga terlibat, termasuk badan hukum yang dimiliki oleh bank atau pihak terafiliasi.

Nasabah bank adalah nasabah penyimpan yang sekaligus juga sebagai nasabah-nasabah Debitur, bank wajib tetap merahasiakan keterangan tentang nasabah dalam kedudukannya sebagai Nasabah Penyimpan. Keterangan mengenai nasabah selain sebagai Nasabah Penyimpan, "bukan merupakan keterangan yang wajib dirahasiakan". Penjelasan pasal 42 ayat (1); ijin oleh Pimpinan Bank Indonesia akan diberikan sepanjang permintaan tersebut telah memenuhi ketentuan sebagaimana dimaksud dalam ayat (3), dan harus dilakukan selambatlambatnya 14 (empat belas hari) setelah dokumen permintaan diterima secara lengkap.

Praktek-Praktek ketidak wajaran dan Penyimpangan yang dilakukan oleh managemen Bank dalam transaksi valas pada umumnya tidak didasarkan pada underlying transaction yang jelas, limitation tidak wajar berubah-ubah, kecenderungan deal dengan counterparty tertentu, menggunakan rate off the market, tidak didukung dengan counterparty tertentu, menggunakan rate off the market, tidak didukung dengan out going/in-coming confirmation yang memadai, tidak dilakukan back-up rekaman pada telpon record, squaring position menggunakan del data, tidak didukung/kontrak perjanjian lemah, revaluasi tidak didasarkan kepada mark to market, settlement tidak dilakukan sebagaimana mestinya. Didalam transaksi trade finance terdapat pula pemberian L/C non L/C fiktif, negotiating/accepting/iccuing bank merupakan kelompok usaha yang sama termasuk juga beneficiary dan applicant. Inti dari rekayasa transaksi tersebut 
untuk memenuhi kepentingan pemegang saham dan atau pengurus bank yang pada dasarnya menggunakan bank sebagai "cash-cow" sehingga sangat membahayakan kelangsungan usahanya.

Kajian-kajian legal semiotik yang berangkat dari paradigma strukturalisme konflik dengan nuansanya yang Neo Marxian, adanya kesengajaan kelas mapan untuk mengembangkan suatu linguistic coordinate system yang mendominasi percaturan hukum amatlah nyata diungkapkan dan dikritik. Undang-Undang Perbankan sejak penjajahan Belanda hingga sekarang masih bersifat merahasiakan kepentingan nasabah dan pelaku perbankan yang beritikat buruk atau penyimpangan-penyimpangannya sulit didapatkan sekalipun oleh alat pemerintah, jaksa atau penyidik. Untuk mendapatkan alat bukti dari Bank yang namanya "alat bukti surat" asli tidak pernah bisa didapat dari Bank yang menyimpannya, walaupun sudah ada pasal yang mengatur tentang penyitaan dokumen dalam Pasal 43 KUHAP yang menyatakan; "penyitaan surat atau tulisan lain dari mereka yang berkewajiban menurut undang-undang untuk merahasiakannya, sepanjang tidak menyangkut rahasia negara, hanya dapat dilakukan atas persetujuan mereka atau atas ijin khusus ketua pengadilan negeri setempat kecuali undang-undang menentukan lain". ${ }^{66}$ Walaupun sudah ada ijin khusus penyitaan dari Pengadilan Negeri, juga untuk mendapatkan keterangan harus ijin Direktur Bank Indonesia melalui Kapolri dalam tingkat penyidikan, dan Jaksa Agung dalam tingkat penyidikan oleh Kejaksaan; sedangkan pasal 40 Undang-Undang No. 10 Tahun 1998 menyatakan Bank wajib merahasiakan keterangan nasabah penyimpan dan simpanannya, disini pasal ini digunakan sebagai payung pelaku penyimpangan dalam tindak pidana dibidang perbankan yang dilakukan oleh nasabah atau pelaku perbankan.

Dalam hal ini hukum digambarkan sebagai teks-teks normatif yang tersusun dalam berbagai linguistics signs yang teknis dan khas yang diakui atau tidak sesungguhnya mengandung sebagai pesan kepentingan para pembuat dan

${ }^{66}$ Abdul Hakim dkk, Kitab Undang-Undang Hukum Acara Pidana dan PeraturanPeraturan Pelaksana, Penerbit Djambatan, Jakarta 1986. 
pensirkulasinya yang umumnya lebih tanggap pada kepentingan dari pada kepentingan khalayak umum. Pada akhirnya teks-teks perundang-undangan dengan posisinya yang dominan dalam percaturan hukum nasional, sebagaimana diproduksi oleh para politisi di badan-badan legislatif dan sebagaimana diinterprestasi menurut doktrin-doktrin kaum positivis dibadan-badan yudisial yang serba simantik; lalu menjadikan khalayak awam teralienasi dari segala bentuk proses pendayagunaan hukum yang mendambakan interprestasiinterprestasi yang lebih substantif. Dalam hubungan ini dapatlah diingat, sebagai salah satu contoh kasus tindak pidana perbankan dana talangan BLBI yang tersangkanya Sahril Sabirin, pada zamannya Presiden Gusdur dapat dihukum, sama-sama mengenai dana talangan tetapi dalam pemerintahan Presiden Megawati Sahril Sabirin dibebaskan atas tuduhan penyimpangan dana BLBI. Sedangkan dalam kasus lain terhadap kasus korupsi Akbar Tanjung, tentang perbedaan menaksirkan makna unsur “kerugian negara" antara Jaksa Penuntut dengan Pengacara Pembela Akbar Tanjung dibebaskan.

Nasib orang kecil di hadapan hukum Indonesia begitu buruknya, kesenjangan demikian besar dalam hal akses untuk mendapatkan keadilan hukum telah menjadikan kenyataan sehari-hari terhadap masyarakat miskin. Ia betul-betul nyata hadir dihadapan kita semua dan akibatnya dapat dengan mudah dikenali. ${ }^{67}$ Sekarang ini Indonesia berada pada masa transisi menuju demokrasi. Pertanyaannya dalam kondisi yang seperti sekarang ini; apakah dengan kondisi sistem hukum seperti sekarang ini proses transisi ini akan berjalan mulus? Dalam proses transisi tersebut sistem hukum seharusnya menjadi sarana yang efektif bagi upaya untuk memberikan penilaian yuridis yang jelas tentang praktikpraktik penyalahgunaan kekuasaan dimasa lalu maupun masa sekarang.

\footnotetext{
${ }^{67}$ Winarno Yudho dkk, Sosok Guru dan Ilmuwan yang Kritis dan Konsisten, Kumpulan Tulisan Peringatan 70 Tahun Profesor Soetandyo Wignjosoebroto, Pencipta Pelajar Offset, Jakarta,2002: 237-238.
} 
Bukti-bukti kebijakan yang salah dan tanpa hati nurani membebani rakyat itu antara lain obligasi rekapitalisasi, penjualan aset-aset BUMN strategis, divestasi Indosat, bank rekapitalisasi dan pemberian Bantuan Likuiditas Bank Indonesia (BLBI). Tentang obligasi rekapitalisasi, Hutapea mengatakan bahwa beban obligasi rekapitalisasi perbankan yang nilai pokoknya mencapai $\mathrm{Rp} 430$ triliun. Jika dibayar tepat waktu, bunganya mencapai Rp 600 triliun. Hal ini akan membebani pemerintah sebesar Rp 1.030 triliun.

Walaupun dalam Undang-Undang Perbankan ada sanksi yang cukup berat mengenai pidana dan denda, namun kenyataannya dalam praktik-praktik penegakan hukum pidana dalam bidang perbankan khususnya BLBI banyak menemui hambatan, karena adanya kebijakan oleh pelaku perbankan dalam menetapkan kebijakan dan cakupan rahasia bank.

Pemerintah sekarang ini ditengarai sama sekali tidak mau tau penderitaan rakyat. Masalah yang dihadapi oleh bangsa Indonesia saat ini adalah tipisnya atau tidak adanya legitimasi pemerintahan di mata masyarakat. Sehingga apapun kebijakan yang diambil sudah tidak populer atau tidak mendapat respons positif dari masyarakat ${ }^{68}$.

Reformasi perbankan nasional yang telah berjalan selama lima tahun terakhir telah memberikan berbagai aspek positif maupun negatif. Jika hanya berpihak pada sisi perbankan, boleh dikatakan reformasi telah mengembalikan tingkat kepercayaan masyarakat sehingga industri perbankan dapat menata dirinya lebih baik lagi guna mengembalikan jati dirinya sebagai intermediasi keuangan yang handal. Namun demikian, untuk menuju ke sasaran tersebut, jelas perbankan tidak dapat bekerja sendiri. Berbagai aspek yang melingkupi kehidupan perbankan perlu juga dikendalikan ke arah yang semakin kondusif ${ }^{69}$.

\footnotetext{
${ }^{68}$ Artikel Majalah JURNAL, Keresahan Masyarakat Meluas, Potensi Konflik Menguat, Edisi Februari, 2003, hal 30.

${ }^{69}$ Ibid, hal 97.
} 


\section{DAFTAR PUSTAKA}

Arif Sritua, 2001, IMF/Bank Dunia dan Indonesia, Muhammadiyah University Press, Surakarta.

Bank Indonesia, 2002, Mengurai Benang Kusut BLBI Bank Indonesia, Perpustakaan Nasional: Katalog Dalam Terbitan (KDT) Bank Indonesia, Jakarta.

Hakim Abdul dkk, 1986, Kitab Undang-Undang Hukum Acara Pidana dan Peraturan-Peraturan Pelaksana, Penerbit Djambatan, Jakarta.

Majalah JURNAL, 2003, Keresahan Masyarakat Meluas, Potensi Konflik Menguat, Edisi Februari.

Mardi Mulyo, 2000, Bank Indonesia Menuju Independensi Bank Sentral, PT. Mardi Mulyo, Jakarta.

Pilang Yasraf Amir, 2001, Sebuah Dunia Yang Menakutkan, Mesin-mesin Kekerasan Dalam Jagat Raya Chaos, Mizan, Bandung.

Rahardjo Satjipto, 2003, Ilmu Hukum : Pencarian, Pembebasan, Pencerahan, Catatan-catatan Kuliah Ilmu Hukum dan Teori Hukum, Semarang, Program Doktor Ilmu Hukum.

2002, Polisi Sipil Dalam Perubahan Sosial di Indonesia, Jakarta, Penerbit Buku Kompas.

, 2002, Sosiologi Hukum, Perkembangan Metode dan Pilihan Masalah, iSurakarta, Penerbit : Muhammadiyah University.

2000, Mengajarkan Keteraturan Menemukan Ketidakteraturan (Teaching Order Finding Disorder), Pidato mengakhiri masa jabatan sebagai Guru Besar Tetap pada Fakultas Hukum Universitas Diponegoro.

1998, Polisi dan Masyarakat dalam Era Reformasi, Jakarta, Fakultas Ilmu Sosial dan Ilmu Politik UI.

Stanford Charles, 1989, The Disorder of Law, A Critique of Legal Theory, Brasil Blackwell. 
Wijaya Krisna, 2003, 5 Tahun Reformasi Indonesia : "Lima Tahun Reformasi Perbankan (1998-2002)”; Beberapa Cacatan, Pengurus Daerah Persatuan Purnawirawan POLRI Daerah Jawa Tengah, Semarang.

Yudho Winarno dkk, 2002, Sosok Guru dan Ilmuwan yang Kritis dan Konsisten, Kumpulan Tulisan Peringatan 70 Tahun Profesor Soetandyo Wignjosoebroto, Pencipta Pelajar Offset, Jakarta. 